\title{
Muzikoterapeutická intervence u klientů se specifickými vzdělávacími potřebami
}

\section{Music Therapy Intervention for Clients with Special Educational Needs}

\author{
Lenka Kružíková몰 Univerzita Palackého v Olomouci, Olomouc
}

\begin{abstract}
Abstrakt
Příspěvek se zaměřuje na hudební podporu vybraných klientů v rámci muzikoterapeutické intervence. Východiskem jsou autorčiny zkušenosti z hudebně-expresivní praxe, výsledky výzkumu a zahraničnímetody u klientů se specifickými vzdělávacími potřebami. Autorka prezentuje princip práce s kontaktní písní, která v muzikoterapii slouží k podpoře klienta, nastavení bezpečného a důvěrného prostředí. Hudební kompozice v muzikoterapii apeluje na odlišné hudební myšlení (včetně notových záznamů a kazuistických př́kladů).
\end{abstract}

\section{Klíčová slova}

muzikoterapie, hudební podpora, klient se specifickými vzdělávacími potřebami

\section{Abstract}

The paper focuses on music support for selected clients within a music therapy intervention. The starting point is the author's experiences from music-expressive practice, research results and foreign methods for clients with special educational needs. The author presents the principle of working with contact songs, which support the clients in music therapy and setting up safety and confidential environment. Music composition in music therapy appeals to different thinking in music (including music sheets and case studies).

\section{Keywords}

music therapy, music support, client with special educational needs

\section{Úvod}

Hudební podpora je nedílnou součástí muzikoterapeutického setkávání. V souvislosti s hudebně-expresivní intervencí chápeme hudební podporu jako spektrum kontaktu a komunikace s klientem, může mít podobu hudební i nehudební, verbální i neverbální. Vnímáme ji jako aktivitu projevu jakési hudební empatie, kotvení klienta v prostoru a čase, a současně jako maximální využití takových hudebních výrazových prostředků, které pracují na pokroku klientovy osobnosti. Na rozvoji terapeutického vztahu se v mnohém podílí hudební souznění s klientem. Proto je velmi důležité dbát na bezpečné a důvěrné prostředí a vytvořit tak pro klienta rituály doprovázené kontaktními písněmi. Kontaktní písně aplikujeme i v průběhu muzikoterapeutického setkání, hudební výrazové prostředky volíme na základě stanovených cúlů. U klientů s mentálním postižením, poruchami autistického spektra, kombinovaným postižením volíme takové podpůrné písňové aktivity, které pomohou rozvinout jejich potenciál s ohledem na jejich specifické projevy chování. Odlišnost ve vnímání hudby a jejího maximálního využití v muzikoterapeutickém kontextu je specifickým přístupem, který zároveň koncepčně pracuje s metodami hudební kompozice, hudební improvizace, hudební interpretace a poslechem hudby. 


\section{Východiska pro kontakt v muzikoterapii a kontaktní písně}

Hudební podpora se v rámci muzikoterapeutického procesu realizuje na základě potřeby klienta. Mưže mít současně podobu hudební, pohybovou/taneční, dramatickou, výtvarnou, literární. Každá z těchto expresivních složek poukazuje na to, že hudba mnohdy není v muzikoterapii monotematická, a že je důležité vnímat celkový kontext klienta a jeho aktuální fyzické a psychické nastavení.

S kontaktováním klienta v muzikoterapii hudebním a nehudebním způsobem jsou spojeny rituály, tedy situace, které se opakují a současně poukazují na strukturu setkání, zdůrazňují bezpečné a důvěrné prostředí a současně podporují klienta v jistotě, jelikož ví, co ho čeká a co bude následovat. Příklady rituálů u dětí s mentálním postižením (dále jen MP), s poruchou autistického spektra (dále jen PAS) (Müller, 2020). Jsou děleny na rituály hudební (např. zvonění zvonečku nebo zvonkohry Koshi, jednoduchý motiv hrou na hudební nástroj, jakýkoli zvukový nebo hlasový projev, písně) a nehudební (např. neverbální pozdrav: oční kontakt, mimika, gestika, pohybová aktivita: poskok s výkřikem, taneční figura, sdílený rytmus apod.). Skupinové rituály v muzikoterapii představuje podrobně Pavlicevic (2003). Stálé rituály zařazujeme většinou na úvod či závěr setkání a mnohdy mají podobu kontaktních písní.

Kontaktní píseň reflektuje náladu klienta, zpř́ítomňuje ho v prostoru a čase, napomáhá rozvoji terapeutického vztahu, má sociální charakter. Kružíková (2020, s. 58) charakterizuje kontaktní píseň jako „specifický druh kontaktu s člověkem v rámci muzikoterapeutické intervence, je možnéji však použít i v hudebně-edukačním procesu. Nutno mít na paměti, že hlas k dítěti promlouvá, aktivizuje jeho pozornost, umožňuje navození relaxačního stavu a empaticky reaguje na jeho potřeby." Často muzikoterapeuti komponují písně přímo pro klienty individuálně a vycházejí tak maximálně z potřeby člověka a naplnění muzikoterapeutického cíle. ${ }^{2}$ Jak uvádí Nordoff-Robbins (2006) písně pro podporu klienta vznikají spontánně na základě aktuálního hudebního a nehudebního dění. Zahraniční modely (Nordoff-Robbins, 1980; Schwartz, 2012; Wheeler, 2017, Pavlicevic, 2003 a další) zmiňují v souvislosti s kontaktními písněmi tzv. Hello Songs nebo Opening Songs (písně pro přivítání v úvodní části muzikoterapeutického setkání), Goodbye Songs nebo Closing Songs (písně s tématem loučení v závěru muzikoterapeutického setkání), Naming Songs (písně o jméně klienta). Muzikoterapeut zohledňuje, co má klient rád a na to hudebně navazuje, proto vznikají písně s herní tematikou, tzv. Play Songs.

Podle toho, jakým způsobem klienti vyhledávají hudbu a jakou roli zastupuje v jejich životě s ohledem na vývojové hledisko, generalizuje Schwartz (2008) písně v muzikoterapii pro potřeby dětí raného věku. Status písně je těsně spjat s vývojovými stupni: důvěra, vědomí, nezávislost, kontrola a zodpovědnost. Schwartz (2012) vytvořila okruhy písní, které se cíleně zaměřuí na určitou podporu klienta ve specifických situacích: shromaždovací písně (Gathering Songs), písně s herním charakterem (Embedded Songs), písně o lidských poutech (Bonding Songs), přechodové písně (Transition Songs), instrumentální písně (Instrument Songs), pohybové písně (Movement Songs), písně o mně (Songs about Me), písně o mém světě (Songs about My World).

Na základěkomparační analýzy generalizovala Kružíková(2013)české a americké kontaktní písnězhlediska hudebního přivítání, navázání a rozvoje terapeutického vztahu, vyvedení klienta z pasivity, aktivizace pozornosti, hudební podpory klientovy osobnosti a hudebního loučení. Jsou jimi: písně na přivítání, písně o jméně, písně aktivizační, písně na téma přátelství a vztahy, písně na rozloučenou. Na komparační analýzu podrobněji navazoval výzkum zaměřující se na sdělení v textech kontaktních písní (Kantor, Kružíková, 2016).

Z hlediska využitelnosti kontaktních písní ve speciálně pedagogické praxi upozorňuje autorka na jejich jednotlivé cíle v jeho protikladech. Hello song jakožto rituál pro děti s PAS může požadovat jasnou strukturu a neměnnost, zatímco DePriest (2012) záměrně mění a variuje styl kontaktní písně v úvodu s cílem adaptace na změnu a narušení repetitivní struktury. Zakladatelé modelu Kreativní muzikoterapie (Nordoff, Robbins, 2006) pro děti se specifickými vzdělávacími potřebami (dále jen SVP) pracují s procedurální a strukturální rolí hudby v úvodu setkání, která má navázat hudební komunikaci, rozvíjet pozitivní vztah a oslovit alespoň část klientovy hudební osobnosti.

Mnohdy muzikoterapeuti navazují na improvizační situace, které následně převádějí společně s klientem do písně - zohledňují náladu klienta (harmonie, melodie, barva), aktivitu (metrum, rytmické struktury), samotný průběh procesu (dynamika). Muzikoterapeut vtahuje klienta do hry strukturovanou, připravenou nebo i nepřipravenou formou: hraje nebo zpívá doprovod, rytmicky kotví klientovo hudební vyjádření, hudebně reflektuje náladu, imituje zvuky, provokuje ke změnám a narušuje hudební stereotypy.

2 Podrobný soupis a komparace českých a amerických kontaktních písní in Kružíková, 2013. 
Jedním z činitelů, které apelují na aktivizaci a kontakt je dech. Práce s dechem má u klientů se SVP nesmírný význam, na což upozorňují studie zástupců Vocal Therapy (Austin, 2008; Stemple a Hapner, 2014) (viz Kazuistický případ č. 1). Hluboký dech pomáhá ke zklidnění tělesných funkcí (srdeční tep, pomalejší nádech a výdech), k vnímání tělesného schématu, sebeuvědomění vlastního Já, reguluje napětí v těle, uvolňuje úzkost. ${ }^{3}$

Kazuistický případ č. $1^{4}$

Petra (3 roky, těžké kombinované postižení, DMO, zbytky zraku, těžké mentální postižení, sociální deprivace)

Dívka se účastnila každý týden individuální muzikoterapie v dětském centru, kde byla umístěna. Muzikoterapeutka se snažila navázat kontakt v náručí se společným sdíleným dechem, následně brumendem (vždy s výdechovým proudem). Po několika setkáních začala dívka otevírat ústa a projevovat snahu o komunikaci. Dalším cílem byla tedy podpora preverbální komunikace (se zvukovou a hmatovou kontrolou) a strukturovaným zvukem, který byl ohraničen diatonickou stupnicí vzestupně a sestupně. Každý tón muzikoterapeutka zpívala s výdechovým proudem dívky (brumendo, otevřený neurčitý vokál, následně zpěv na „lá" nebo "há“). Dívka projevovala zájem, měla radost, vědomě komunikovala a sama navazovala kontakt brouknutím, výdechem.

\section{Hudební komponování v muzikoterapii u klientů se SVP}

Hudební komponování v muzikoterapii účinně ovlivňuje pokrok a rozvoj dítěte. Jestliže se zaměříme na cílovou skupinu dětí a žáků se SVP v inkluzivním prostředí, nabízí se i hudební spolupráce a podpora ze strany intaktní populace. Netradičním zpo̊sobem chápání hudby tak můžeme obohatit obě strany zúčastněných a integrovat tak jejich schopnosti a dovednosti do hudebního celku. Hudba má následně uchopitelnou výpovědní hodnotu, která upevňuje inkluzivní proces a samovolně vytváří přátelské a empatické prostředí.

Základním kritériem pro kompozici písně v muzikoterapii dětí a žáků s postižením je její jednoduchost. Melodie a text jsou snadno zapamatovatelné, harmonie klienta provází a neměla by ho vytrhnout z jeho kreativního procesu. Jestliže je hudební produkt přístupnější, vstupujeme tak snadněji do komunikace a můžeme také ihned reagovat zvukem, hlasem, hudebním nástrojem, pohybem. Hudební kontakt může představovat i krátký hudební motiv, který aplikovala ve své praxi Alvin (1978) u chlapce s PAS. Vytvořila diatonickou řadu stupnice $\mathrm{C}$ dur s textem „Robert is a very Good Boy“. Jednoduché a pro klienta zásadní sdělení má jasnou strukturu a koncepci, vyjadřuje podporu a empatii.

Hudba plně koresponduje s muzikoterapeutickým cílem, doplňuje ho a je autentická. V hudebním vyjádření přizpůsobujeme nejen tóninu, dynamiku a agogiku písně, ale také melodické kroky a intervalové skoky. Hudební zkušenost dítěte se SVP by měla být do hudebního díla promítnuta. U dětí s PAS často zařazujeme nap̌r. repetované tóny, opakované rytmické struktury, stereotypní melodické struktury, čímž reflektujeme hudebně-expresivní proces. Jestliže klientově hudbě muzikoterapeut naslouchá pozorně, může zaznamenat různé hudební exprese, vokalizaci, pohyby, hudební impulzy, což Birnbaum (in Kružíková, 2013) nazývá Careful Listening.

Komponování písně přímo pro klienta se SVP vychází z jeho potřeby, na kterou navazuje stanovený cíl a muzikoterapeutická intervence, se kterou se pojí sdělení písně, text. Dalšími částmi hudebního procesu je volba metra, rytmu, tóniny, melodie a intervalů (viz Obr. 1).

3 V praxi se nabízí technika „Sdílení dechu“, kterou popisují autorky (Friedlová a kol., 2020, s. 85).

4 Nutno podotknout, že veškeré údaje o klientech jsou uváděny v souladu s etickým kodexem, tudíž jejich jména byla v zájmu zachování anonymity změněna. 


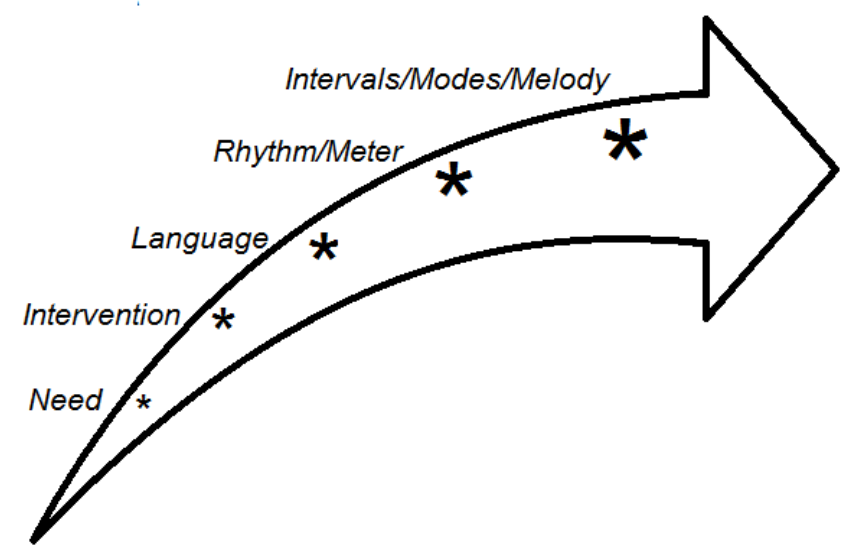

Obr. 1 „Creating a therapeutic song“ (Morris, Willoughby \& Schwartz, 2012).

Přizpůsobení hudebních výrazových prostředků v praxi znamená, že pokud vytváříme píseň o tělesném schématu, respektujeme tělesné proporce, které zároveň zohledňujeme i v melodii a její výšce. Hudba pak sama klienta vede k naplnění cíle, aniž bychom ho verbálně upozorňovali nebo neverbálně provázeli (viz Kazuistický př́ípad č. 2 a Obr. २).

Kazuistický př́ipad č. 2

Magda (6 let, těžké kombinované postižení/DMO)

„V rámci individuální muzikoterapeutické intervence byla pro potřeby dítěte komponována píseň s námětem těla. Východiskem potřeby bylo tedy poznání těla, jeho zvědomění, práce s tělesným schématem v prostoru, sebeuvědomění a podpora Já. Text byl zvolen systematicky od hlavy po palce u nohou se závěrem „Tohle všechno jsem Já“" Sudé metrum bylo zvoleno pro snadnější orientaci klientky. Melodie jde souběžně s pozicemi těla tak, aby dítě vedla a motivovala. Píseň je možno aplikovat u různých cílouǵch skupin."(Müller a kol., 2020, s. 183)

\section{Tohle všechno jsem já!}

\section{Kružíková}
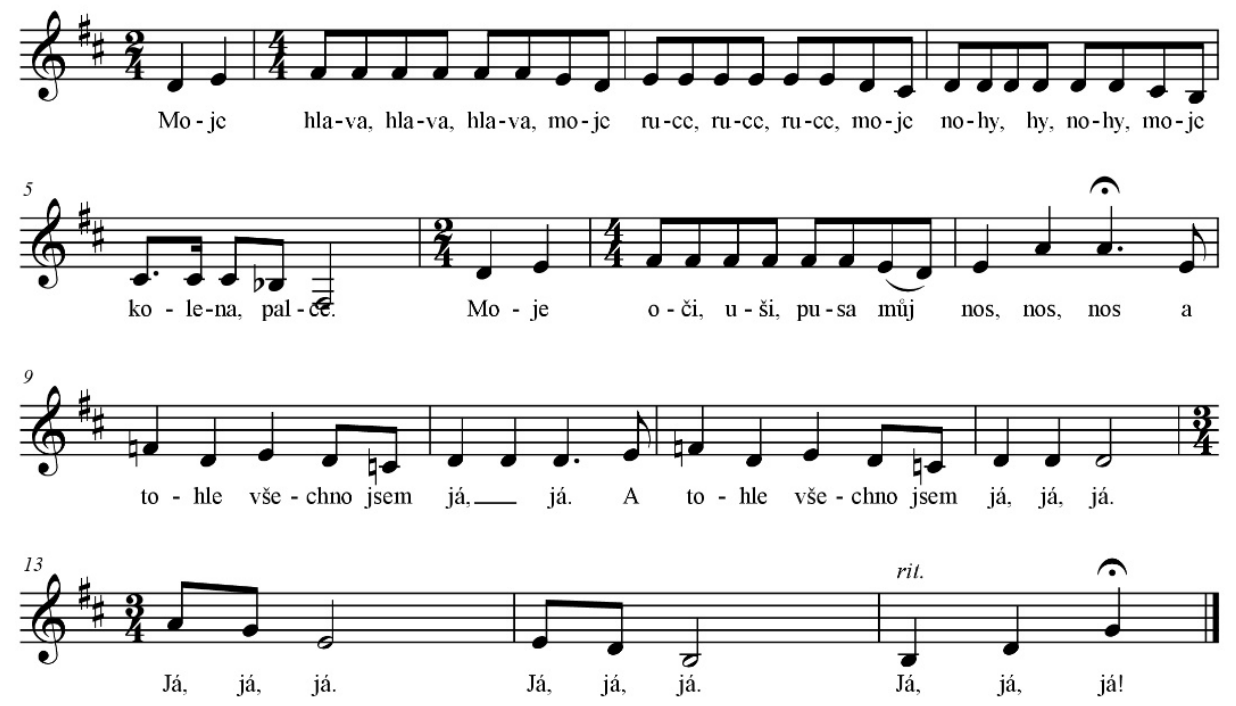

Obr. 3 „Tohle všechno jsem já!“ Zdroj: archiv: L. Kružíková.

Aktivní využití hudebních výrazových prostředků, především jejich pestrost, umožňuje naplňovat nehudební a hudební cíle. Rytmus pomáhá strukturovat muzikoterapeutický proces, aktivuje pozornost, kotví

5 Podrobněji je píseň a technika „Tohle všechno jsem já!“ popsána v publikaci Hudební didaktika pro žáky se SVP v inkluzivním vzdělávání (Kružíková, 2020, s. 72). 
klienta v prostoru a čase, poskytuje hranice, žádoucí stereotyp (opakování), navozuje pocity jistoty a bezpečí. Systematickou studii rytmu a temporálních dovedností můžeme nalézt v modelu Kreativní muzikoterapie Nordoff-Robbins (2006), který na základě rytmické svobody a rytmické koordinace evaluuje hudební projev klienta se SVP a také to, jakým způsobem vstupuje do hudebních interakcí. U dětí s PAS rozpracovala metodický návod práce s rytmem a jeho časovou délkou Alvin (1978), vnímání symbolů reprezentuje časovou délku rytmického úseku ve spojitosti s pohybem.

Jestliže navážeme na metrické vztahy - v českém prostředí máme zakódováno především dvoudobé a třídobé metrum. Při práci s dětmi s PAS můžeme jako ukázku dobré praxe zmínit metodickou aplikaci hudební formy RONDO (ve schématu A-B-A-C-A-D-A-E-A...) ${ }^{6}$. Hlavní téma A reprezentuje píseň v libovolném taktu. Jurkovič (2012) při rondo-práci s dětmi zmiňuje píseň Šla kočička k muzice. Téma A následně zpívají všichni společně. Dílčí témata nabízí jednoduchá říkadla ve stejném taktu, ve kterém je zapsána píseň hlavního tématu. V průběhu techniky se střídá píseň s říkadlem (ta jsou interpretována libovolně: opera, rap, metal, pantomima, tanec apod.). Možné srovnání nabízí Jurkovič (2012) také ve tříčtvrtovém taktu, kde se při jeho vnímání více aktivně zapojuje kooperace pravé a levé mozkové hemisféry.

Pestřejší aplikaci nestandartního taktu u klientů se SVP nabízí píseň Schwartz (2012) Shake Five (viz Obr. 4). Práci s pětidobým metrem rozděluje na vnímání tří a dvou a zároveň jej propojuje s pohybem. V praxi to vypadá tak, že jdeme tři kroky střídavou chůzí vpřed a dva kroky střídavou chůzí vzad. Výsledek je následně hmatatelný v prostoru a názorně poukazuje na to, že klient jde vždy dopředu, směřuje viditelně k pokroku (což můžeme přenést i do jeho životních zkušeností). Prostřednictvím této techniky podporujeme kotvení v prostoru, nácvik prostorové orientace, tandemový pohyb, motivujeme k pokroku a k upevnění sebevědomí. ${ }^{7}$

\section{Shake Five}

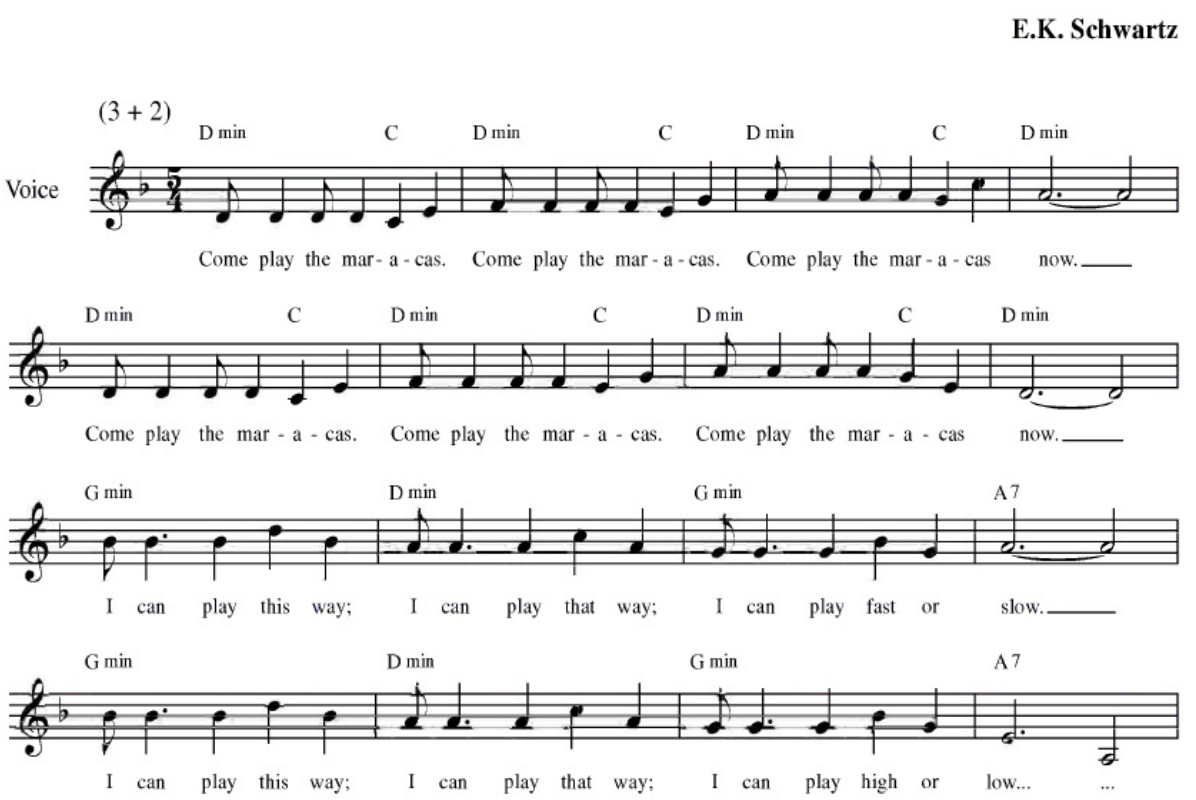

Obr. 4 Shake Five (Schwartz, 2012, s. 87).

\section{Techniky hlasové podpory v muzikoterapii u klientů se SVP}

Hlas je v hudebně-expresivní intervenci tím nejcennějším nástrojem podpory, dokáže okamžitě empaticky reagovat, jelikož ho máme neustále u sebe, často navazuje přátelské, důvěrné a bezpečné prostředí díky své intonaci a barvě. Hlasová podpora také dokáže v muzikoterapeutickém procesu navodit velmi intimní atmosféru a pomoci klientovi k emoční abreakci. S tím souvisí i hlasová vibrace, která uvolňuje fyzické a psychické napětí v těle.

České prostředí dosud nenabízí podrobné zpracování a definice metod a technik hlasové podpory. Jakožto inspirační zdroj můžeme tedy poukázat na Voice Work Austin (2008), jejíž metodika vychází z vlastní psychoterapeutické praxe. Austin (2008) definovala následující metody hlasové podpory:

6 Podrobněji technika popsána pro děti s PAS, děti raného věku intaktní populace, klienty seniorského věku gerontologických oddělení psychiatrické kliniky, děti předškolního věku romského etnika v publikaci Kružíková, 2020, s. 69).

7 Podrobněji in Friedlová a kol. (2020, s. 90). 
- Toning: vědomé použití vokálo̊, neverbálních zvuků a zvukových vibrací pro obnovení tělesné a psychické rovnováhy.

- Vocal Holding: založeno na vokální improvizaci, terapeut současně doprovází a kotví klienta prostřednictvím jednoduchého harmonického klavírního doprovodu pro bezpečnou strukturu.

- Free Associative Singing: vychází z Freudových volných asociací, terapeut dubluje slova klienta, reflektuje jeho zkušenost jako součást vokální improvizace.

- Psychodramatic Singing: aplikuje symboly a imaginaci, při níž dochází k bezpečnému zpracování zkušenosti a externalizaci emocí.

Z podpůrných hlasových technik můžeme dále jmenovat „...intuitivní zpěv, který se soustředí na aktuální reakci a naladění. Intuitivně a empaticky se hledá cesta hlasové podpory tak, aby došlo k progresu v chování dítěte. Provázený a komentovaný zpěv znamená potvrzení zkušenosti dítěte, popis a reflektování uplynulé situace. Dítě je kotveno v reálné situaci a činnosti (vhodné zejména u dětí s poruchou autistického spektra - PAS). Podobný příklad hlasové podpory ve vnímání reálného prostoru je vokální kotvení. Tento grounding (tedy kotvicí) proces vytváří hudební prostředí opakovaného hudebního motivu (i několika tónů), stabilního rytmu." (Kružíková, 2020, s. 63)

Kružíková (2016) generalizovala specifický druh hlasové podpory u dětí s PAS, která pracuje se sdílenou zkušeností, aktuální situací a činností klienta. Díky sdílené hlasové pozornosti dochází k empatické hudební komunikaci a naplnění muzikoterapeutických cílů. Hudební komunikace zvuková interpretuje zvukové projevy klienta, terapeut na ně reaguje zrcadlícími a imitačními technikami, někdy se ke zvuku v rámci setkání vrací i ve zdánlivé nesouvislosti. Hudební komunikace intonační pracuje s krátkými melodickými útvary, kdy terapeut často vychází právě z referovaných zvuků, které následně rozvádí v krátký hudební motiv několika tónů (stereotypně se opakujících). Hudební komunikace vokálně-verbální motivuje klienta k hlasové a verbální interakci: aplikuje slabiky, slova, slovní spojení, fragmenty vět, jež jsou spojovány v personální hudební nápěvek. Autorce se při práci s klienty s PAS v tomto případě osvědčil princip tzv. joiku (zpěv sámské lidové kultury, viz Kazuistický případ č. 3)

Kazuistický případ č. 3

Helena (7let, nízkofunkční autismus, muzikoterapeutická intervence začala v jejích 3,5 letech)

„Dívka v muzikoterapii vždy pozitivně reagovala na zpěv, hlasovou podporu a hudební komunikaci se zvuky. V průběhu muzikoterapeutického procesu tedy díky ní vznikl specifický přístup hlasové podpory ke klientovi s poruchou autistického spektra, který primárně vychází ze sdílené zkušenosti, respektuje zvuková vyjádření, na která navazuje, hudebně je rozvíjí a variuje, a následně melodicky klienta kotví za podpory jeho vyjadřování prostřednictvím joiku. Dívka opakovala slovní spojení, sama vstupovala do melodické komunikace, vydala se k pianu, dotkla se jej a znovu odešla. Postupně tak docházelo ke komunikačnímu tanci s terapeutkou. Časový zájem o hru na piano s hlasovou podporou se prodlužoval, až dívka sama seděla u piana a snažila se objevovat jeho zuuky rukama i nohama." (Kružíková, 2016, s. 157)

\section{Závěr}

Expresivní přístupy umožňují pomocí hudebních a nehudebních vyjadřovacích prostředků rozvíjet a podporovat v klientech schopnosti a dovednosti, které by jinak zůstaly skryté. Hudba ke klientovi promlouvá: u dětí a žáků s PAS se může stát mostem mezi světy a podporou sociálního kontaktu a komunikace, u dětí a žáků s mentálním postižením pomáhá k adaptaci, podporuje proces učení, u dětí a žáků se zrakovým postižením podporuje zrakovou stimulaci a prostorovou orientaci, u dětí a žáků s tělesným znevýhodněním podporuje motoriku a tělesnou koordinaci, u kombinovaného postižení může hudba nabídnout multisenzorický aspekt, u narušené komunikační schopnosti posiluje mluvidel. Zmíněné cíle jsou jen pouhými příklady (z autorčiny praxe výše zmíněných cílových skupin), nikoli však vyčerpávajícím výčtem. Příspěvek poskytl ukázky dobré praxe hudebně-expresivní oblasti podložené autorskými, českými nebo zahraničními výzkumy. Každý člověk se specifickými vzdělávacími potřebami je jedinečný a tím i jeho hudba. 


\section{Literatura}

Alvin, J. (1978). Music Therapy ort he Autistic Child. New York: Oxford University Press.

Austin, D. (2008). The Theory and Practice of Vocal Psychotherapy: Songs of the Self. London: Jessica Kingsley Publishers.

DePriest, C. (2012). Music Therapy in the Classroom. Presentation for Head Start Teachers and Administrators. Evansville, IN.

Friedlová, M. a kol. (2021). Muzikofiletické techniky v inkluzivní výuce. Olomouc: Univerzita Palackého v Olomouci.

Jurkovič, P. (2012). Od vúkřiku k písničce. Praha: Portál.

Kantor, J., Kružíková, L. Qualitative content analysis of hello songs composed for children by music therapists in the Czech republic and USA. Social Wellfare: Interdisciplinary Approach, 2016, 2(6), 124-137. https://doi.org/10.21277/sw.v2i6.272

Kružíková, L. (2013). Kontaktní písně v muzikoterapii. Komparace hudebního materiálu aplikovaného v českém a americkém muzikoterapeutickém prostředí (nepublikovaná disertační práce). Olomouc: Univerzita Palackého v Olomouci.

Kružíková, L. (2016). Vliv hlasu při muzikoterapeutické intervenci u vybraných klientů. In Sobotková, I., Heller, D., Slezáčková, A. (Eds.) (2017). Psychologické dny 2016. (145-157). Olomouc: Univerzita Palackého v Olomouci.

Kružíková, L. a kol. (2020). Hudební didaktika pro žáky se speciálními vzdělávacími potřebami v inkluzivním vzdělávání. Olomouc: Univerzita Palackého v Olomouci. Dostupné na https://imuza.upol.cz/publikace/Kruzikova-Hudebni-didaktika.pdf

Morris, I. B., Willoughby, S., \& Schwartz, E. K. (2012). Modes, Meter and Meaning: Composing Therapeutic Songs in Early Childhood. In Workshop MAR-AMTA Conference. Baltimore, MA.

Nordoff, P., \& Robbins, C. (1980). Creative Music Therapy. NYC, NY: Nordoff-Robbins Center for Music Therapy, New York University.

Nordoff, P., \& Robbins, C. (2006). Music Therapy in Special Education. Gilsum, NH: Barcelona Publishers.

Müller, 0. a kol. (2020). Metodika expresivních přístupư u žáků se specifickými vzdělávacími potřebami v inkluzivním vzdělávání. Olomouc: Univerzita Palackého v Olomouci.

Pavlicevic, M. (2003). Groups in Music: Strategies from Music Therapy. London and New York: Jessica Kingsley Publishers.

Schwartz, E. K. (2008). Music Therapy and Early Childhood: A Developmental Approach. Phoenixville: Barcelona Publishers.

Schwartz, E. K. (2012). You and Me Makes We. A growing Together Songbook. Melrose, MA: Centre for Early Childhood Music Therapy, LLC.

Stemple, C. J., \& Hapner, E. R. (2014). Voice Therapy: Clinical Case Studies. San Diego, CA: Plural Publishing. Wheeler, B. (ed.) (2017). Music Therapy Handbook. London: The Guilford Press.

\section{Informace o autorce}

\section{Mgr. Lenka Kružíková, Ph.D.}

Odborná asistentka na katedře hudební výchovy Pedagogické fakulty Univerzity Palackého v Olomouci, muzikoterapeutka. Vědecky se zaměřuje na oblast expresivních terapií, hlasové výchovy a na hudební rozvoj dětí raného a předškolního věku. Vystudovala speciální pedagogiku - hudební výchovu, postgraduální studium oboru hudební pedagogika na UPOL a obor edukační muzikoterapie na Pedagogické fakultě Univerzity Karlovy v Praze. Ve své muzikoterapeutické praxi se zaměřuje na podporu dětí raného věku se speciálními vzdělávacími potřebami (především s mentálním a kombinovaným postižením, PAS). Je členkou Muzikoterapeutické asociace České republiky, zasedá v profesní komisi. Absolvovala řadu seminářo̊ a kurzů u nás i v zahraničí zaměřených na terapeutickou oblast.

Email: lenka.kruzikova@upol.cz 